\title{
HSE Management System for Hotwork Operation at High Elevation in Shipbuilding Project
}

\author{
Idris Othman ${ }^{1, *}$, Mohd Fauzan Helmy Ibrahim ${ }^{1}$, Nasir Shafiq ${ }^{1}$, Hisham Mohamad ${ }^{1}$, and Md Salim Kamil ${ }^{2}$ \\ ${ }^{1}$ Universiti Teknologi PETRONAS, Malaysia \\ ${ }^{2}$ Universiti Kuala Lumpur, Malaysia
}

\begin{abstract}
Shipyard industry is one of the growing industry in Malaysia. There is still a lot of room for improvement with regards to the safety aspects within the industry. This study presents the finding of a survey on the safety management in shipyard operation of class $\mathrm{C}$ and D in Peninsular Malaysia registered with Ministry of Finance Malaysia. Shipyard operation is considered a hazardous job. Most of the cases were due to fall from height, fire and explosion. Similar accidents happened in South Korea, where 8 fatalities and 31 injuries were reported in January to August 2017. The accidents were due to crane collapsed and explosion during welding works inside a hull of a Liquefied Petroleum Gas (LPG) carrier. This paper aims to study the Health, Safety and Environment Management System (HSEMS) of shipyard operations in Malaysia particularly in Class C and Class D shipyard. This study was conducted using a survey method following the Glenn D's equation. The survey was targeted at the people who are involved in the industry including the staffs of clients, consultants and contractors. The findings of this study show that almost all the shipyards of Class C and D have HSEMS in placed but some are incomplete. Accidents still happen in the Malaysian shipyard industry from time to time. The gaps in the HSEMS that lead to the accident are highlighted in this paper. Nearly $10 \%$ of Class C and D shipyards do not have clear HSE Policy and this one of possible causes of accidents due to low priority given to HSE matters in this particular Class C and D shipyard.
\end{abstract}

\section{HSE Management System}

The HSE Management System model is well-known comprised of seven interrelated elements with underlying expectations [1]:

- Commitment and Leadership

- Policies and Objectives

- Organization, Resources and Documentation

- Risk Evaluation and Management

- Planning \& Procedure

- Implementation, Recording and Monitoring

- $\quad$ Audit and Review

Each element must communicate these expectations to all employees, customers and third parties associated with organisation business.

One of the hazardous operation is working in shipyard industry where ships are repaired and built [2] [3]. Usually, shipyards are built nearby the sea or river [4]. HSEMS should cover all these activities of shipyard. There are many studies performed on hotwork in confined space [5] [6] [7]. However, there is hardly any studies on procedural of hotwork operation at high elevation but only studies on risks, harms and incidents [7] [8] [9].

The safest working with the hot work environment at high elevation are designed based on managing, controlling and handling all aspects of health, safety and the environment in the shipyard industry [10] [11] [12]. The aims of this studies are to minimise the incidents and accidents during working with hotwork environment at high elevation and to reduce companies' risks litigation simultaneously.

${ }^{*}$ Corresponding Authors: idris_othman@utp.edu.my 


\section{Research Purpose}

This study will attempt to fill in the gap by re-examining the HSEMS in shipbuilding industry in Malaysia. The findings will provide an up to-date understanding towards the current conditions of the local HSEMS shipbuilding industry. The aims of selected shipyard are class C and D which is registered with Malaysian Ministry of Finance (MoF). Perceptions of different shipyard participants on the shipbuilding projects in Malaysia will be examined. The findings of this study will provide the up-to-date information in formulating appropriate strategies to address the challenges brought about by humanrelated issue.

\section{LITERATURE REVIEW}

The safety management role in the shipyard is managed by the operator. For example, in the Daewoo Shipbuilding and Marine Engineering Co. Ltd, shipyard in Korea, the first stage to develop a HSEMS is by identifying the hazard, which known as Hazards Identification (HAZID). Then, it continues with determining the severity of potential hazards. However, most shipyard companies in Malaysia are still keeping their current SOP, and has no or less improvement made on it, as it is least enforced and not fully practiced [13]. The consequences of that, many incidents and accidents occurred in the shipyard such as firing, explosion and objects or human falling down.

\section{1 Leadership}

Due to more recent foreign direct investments by Japanese and Westerners, the traditional patterns of business management and leadership have been modified [14]. They are still governed by their key cultural and religious values which underpin their behaviour, beliefs and attitudes [15].

\subsection{Cultural Approach towards Occupational Safety \& Health (OSH)}

For employers, business managers and OSH professionals striving for excellence in the field of occupational safety and health, the key issue is to ensure that occupational accidents and work-related ill health are prevented as much as possible, and that safe and healthy behaviour among all employees is promoted. In order to achieve continuous improvement of workers' safety and health, a systematic, integrated, proactive, participative, and multiple-strategy approach towards OSH management is needed [16].

\subsection{Policies}

The stages of the policy management process are: defining objectives, setting specific goals, implementing programs and actions, and checking, validating and revising actions and goals. In the case of shipbuilding, because of the huge diversity of industrial organization models, shipyard characteristics, organization of production processes and output patterns, establishing specific performance targets is particularly difficult [17].

\subsection{Organization, Resources and Documentation}

Surveys show that leaders and decision-makers are tending to follow the trend and search for best practices implemented. That happens sometimes without understanding their real organization's needs or assessing their actual requirements and that would put the organisations under a serious risk [18].

In addition, more than 300 injuries happen yearly in the marine industry during the operation. Most accidents occurred during working with hotwork environment at high elevation [19] [20] [21]. In addition, it has been found that the shipyards in Turkey, a huge number of accidents occurred due to falling from high elevations and followed by fire or explosion [19] [22]. The total number of the accidents are about 115 and it's presented in percentage. This accident might cause death or injuries to the workers and financial losses to the employers. Table 1 shows the classification of fatal occupational accidents and percentages of accidents in Turkey.

\section{Methodology}

This study attempts to fill in the gap by re-examining the HSEMS in shipbuilding industry in Malaysia. The findings provide an up to-date understanding towards the current conditions of the local HSEMS shipbuilding industry. The aims of selected shipyard are class C and D which is registered with Malaysian Ministry of Finance (MoF). Perceptions of different shipyard participants on the shipbuilding projects in Malaysia will be examined. The findings of this study provide the up-to-date information in formulating appropriate strategies to address the challenges brought about by human-related issue.

\subsection{Questionnaire Survey}

Questionnaire generally developed based on literature review and might have some modification and amendments [23]. The questionnaire was developed based on Likert Scale in order to scale from which respondents choose one option that best aligns with their view. The respondents identified factors that they perceived as being likely to contribute to the success of the construction project by responding on a scale from 1 (never) to 5 (always). The five-point Likert rating scale was $1=$ Never 2 = Seldom, 3 = Sometimes, $4=$ Often and $5=$ Always. The mean score (MS) for each factor was calculated using the following formula [24] [25]. 


$$
M S=\frac{\Sigma(f \times s)}{N}(1 \ll M S \ll 5)
$$

where $f$ is the frequency of responses to each rating, $\mathrm{s}$ is the score given to each factor by the respondents and ranges from 1 to 5 and $\mathrm{N}$ is the total number of responses concerning that factor. Figure 3 shows the total selected response from responders for HSEMS questionnaire.

\subsection{Questionnaire design}

The questionnaire was divided into different sections, namely:

Sec 1: General Information of the Agency/Organization

Sec 2: Respondent Profile

Sec 3: Success Factors for Successful Completion of Shipbuilding Projects.

\subsection{Focus Group Study}

In the present research, the questionnaire was distributed to respondents that are familiars with shipyard as study. It provides better information to be effective in meeting the objectives of the study [26] [27].

Total of 77 questionnaires were sent to different target groups in the shipbuilding industry. This response rate was finally achieved after several efforts were made in terms of follow-up e-mails and letters.

Despite the limitation of the sampling size, the firms surveyed represent a large proportion of the construction industry outputs and populations. The survey was send to a total of 83 respondents in the shipbuilding industry which comprises of 11 clients, 7 consultants and 65 contractors. These respondents were selected systematic and randomly based on the lists of best performing companies from respective institution [28].

Based on the responses received, three (13.3 per cent) respondents were from clients, followed by four ( 8.4 per cent) from consultant and seven (78.3 per cent) from contractor companies. The response rate of 100 per cent is totally acceptable. Based on reported that the normal response rate in construction research for postal questionnaire is around 20-30 per cent [29]. On the other hand, Dulaimi et. al. reported a 5.91 per cent respond rate for their research survey due to the lack of participation from the construction industry [30]. This statement assumes including the shipbuilding projects as well-known as ship construction projects.

Based on the data obtained from the questionnaire, 3 of them or 3.6\% are owner and project director each followed by 14 of them which represent $16.9 \%$ are project manager. Besides that, 13 of the respondents with $15.7 \%$ are project engineer and 1 respondent or $1.2 \%$ are surveyor. While the supervisor showed 15 respondents or $18.1 \%$ and general worker are 34 respondents or $41 \%$. Thus, it shows that the highest number of respondents are general workers and the lowest were surveyor.

3 respondents or $3.6 \%$ have between 1 to 3 years working experience. This was followed by 6 respondents or $7.2 \%$ between 3 to 5 years. Besides that, there have 14 respondents or $16.9 \%$ between 5 to 10 years and followed by 60 respondents or $72.3 \%$ more than 10 years. This represented the highest number of respondents for working experience is more than 10 years and the lowest are between 4 to 6 years. No respondents between 1 to 3 years. It was followed by 6 respondents or $7.2 \%$ between 4 to 6 years. Then, the respondents more than 10 years comprised of 71 respondents with $85.5 \%$. This illustrated that the highest number of respondents more than 10 years and the lowest allocated by the respondents between 4 to 6 years and 7 to 9 years.

\section{ResUlt \& ANALYSIS}

\subsection{Normality Test}

In statistics, normality test is used to determine if a data set is well-modeled by a normal distribution and to compute how likely it is for a random variable underlying the data set to be normally distributed. Normality is an important concept in statistics because before starting the analyses, the researcher should check a dataset for normality before performing an analysis that relies on normally distributes data. When the data is normal, the test should be conducted using parametric. Based on Table 1, that all factor has a mean and median are very similar and based on the test of significantly found that each factor showed significant level of $\mathrm{p}<0.05$. This showed that it is not normal distribution and is suitable for further analyzed for this study. This means that the test should be conducted using non-parametric although all items are shaped Likert scale. Besides that, the skewness statistic shows the distribution of the data. The all factors show positive skewness where the mean value is greater than the median value. 
Table 1: Test of Normality for Each Factor

\begin{tabular}{lcccc}
\hline \multicolumn{1}{c}{ Factor } & Mean & Median & $\begin{array}{c}\text { Standard } \\
\text { Deviation }\end{array}$ & Skewness \\
\hline $\begin{array}{l}\text { Leadership and } \\
\begin{array}{l}\text { Commitment } \\
\text { Policy and Strategic }\end{array}\end{array}$ & 3.251 & 3.200 & 0.599 & 1.235 \\
$\begin{array}{l}\text { Objectives } \\
\text { Organization, }\end{array}$ & 3.200 & 3.000 & 0.671 & 1.057 \\
$\begin{array}{l}\text { Resources and } \\
\text { Documentation }\end{array}$ & 3.077 & 2.888 & 0.699 & 1.146 \\
$\begin{array}{l}\text { Evaluation and Risk } \\
\text { Management }\end{array}$ & 3.551 & 3.400 & 0.585 & 0.877 \\
$\begin{array}{l}\text { Planning and } \\
\text { Procedures }\end{array}$ & 3.167 & 3.000 & 0.616 & 0.855 \\
$\begin{array}{l}\text { Implementation and } \\
\begin{array}{l}\text { Monitoring } \\
\text { Auditing and }\end{array}\end{array}$ & 3.097 & 2.909 & 0.560 & 1.315 \\
Reviewing & 3.494 & 3.333 & 0.705 & 0.509 \\
\hline
\end{tabular}

Figure 1 showed the distribution of distribution elements reviewing. The result showed, shape of auditing and reviewing are leptokurtic and negative skewness. That means the results is higher kurtosis or higher peak in a normal distribution.

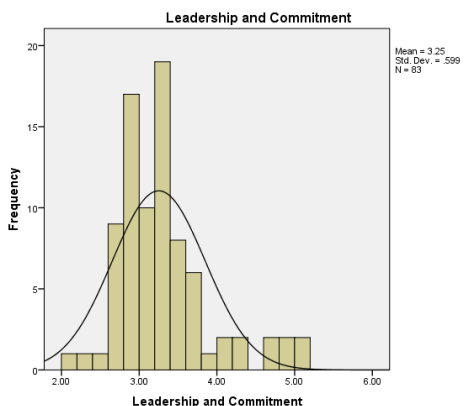

Fig. 1: Distribution of Leadership and Commitment

\subsection{Reliability}

Cronbach's alpha is the tool to investigate the internal consistency (i.e. reliability) of the measures, and Cronbach's alpha reliability coefficient normally ranges between 0 and 1 . According to Sekaran \& Bougie, the closer the reliability coefficient gets to 1.00 the better. They further proposed that reliability less than 0.6 are considered to be poor. Those in the range 0.7 , acceptable and those over 0.8 is good [31].

In this study, 83 respondents were used in the pilot study. As seen in Table 2, all factors showed the result is acceptable. The result is range 0.810 to 0.922 . Based on success factors for successful completion of construction projects showed Cronbach's alpha for leadership and commitment is 0.917 , policy and strategic objectives is 0.917 , organization, resources and documentation is 0.922 , evaluation and risk management is 0.848 , planning and procedures is 0.865 , implementation and monitoring is 0.81 and auditing and reviewing is 0.911 . The overall questionnaire showed Cronbach's alpha is 0.981 . Every questionnaire items is said to be valid because the Cronbach's alpha greater than 6 . So, the data in this study can be classified as good and adequate for this research means.

Table 2: Test of Reliability

\begin{tabular}{lcc}
\hline \multicolumn{1}{c}{ Factor } & $\begin{array}{c}\text { Cronbach } \\
\text { Alpha }\end{array}$ & No of Item \\
\hline Leadership and Commitment & 0.910 & 10 \\
$\begin{array}{l}\text { Policy and Strategic Objectives } \\
\text { Organization, Resources and }\end{array}$ & 0.919 & 9 \\
$\begin{array}{l}\text { Documentation } \\
\text { Evaluation and Risk }\end{array}$ & 0.923 & 9 \\
Management & 0.848 & 10 \\
Planning and Procedures & 0.865 & 11 \\
Implementation and Monitoring & 0.810 & 11
\end{tabular}




\begin{tabular}{ccc} 
Auditing and Reviewing & 0.911 & 9 \\
\hline Overall & 0.981 & 71 \\
\hline
\end{tabular}

\subsection{Relative Important Index}

\subsubsection{Leadership and Commitment}

Table 3 shows the perspectives of Leadership and Commitment from client, consultant and contractor on relative importance of HSE Management System for Hotwork Operation at High Elevation in Shipbuilding Project in a single table. From the comparative view in Table 6, "Managers at all levels ensure that decisions/practices are consistent with HSE policy and objectives" had been ranked as the most important factor by the groups (combining the views of client, consultant and contractor) followed by "Organization employ staff who possess HSE qualification that aim to provide training in more than the basic requirements" and "Organization ensure HSE advisors are competent person".

Table 3: RII of Leadership and Commitment

\begin{tabular}{llll}
\hline Statement & RII & Rank \\
\hline $\begin{array}{l}\text { Top management actively promote positive } \\
\text { HSE culture in the business }\end{array}$ & 0.636 & 6.5 \\
$\begin{array}{l}\text { Organization promote a positive culture } \\
\text { towards HSE matters }\end{array}$ & 0.636 & 6.5 \\
$\begin{array}{l}\text { Organization regularly arranges meetings for } \\
\text { promoting HSE aspects }\end{array}$ & 0.631 & 8 \\
$\begin{array}{l}\text { Organization ensure HSE advisors are } \\
\text { competent person }\end{array}$ & 0.699 & 2.5 \\
$\begin{array}{l}\text { The organization's superintendent discusses } \\
\text { HSE matter at workplace }\end{array}$ & 0.653 & 5 \\
$\begin{array}{l}\text { Safety is priority mention during toolbox } \\
\text { meeting }\end{array}$ & 0.67 & 4 \\
$\begin{array}{l}\text { Senior management and department heads do } \\
\text { HSE inspections frequently }\end{array}$ & 0.564 & 10 \\
$\begin{array}{l}\text { Organization management involved in HSE } \\
\text { activities, objective-setting and monitoring }\end{array}$ & 0.61 & 9 \\
$\begin{array}{l}\text { Organization employ staff who possess HSE } \\
\text { qualification that aim to provide training in }\end{array}$ & 0.699 & 2.5 \\
more than the basic requirements \\
$\begin{array}{l}\text { Managers at all levels ensure that } \\
\text { decisions/practices are consistent with HSE } \\
\text { policy and objectives }\end{array}$ & 0.706 & 1 \\
\hline
\end{tabular}

\subsubsection{Policy and Strategic Objectiveness}

Table 4 shows the perspectives of Policy and Strategic Objectiveness from client, consultant and contractor on relative importance of HSE Management System for Hotwork Operation at High Elevation in Shipbuilding Project in a single table. From the comparative view in Table 7, "Organization really cares about my well-being" had been ranked as the most important factor by the groups (combining the views of client, consultant and contractor) followed by "Organization arranges to ensure new employees have knowledge of basic HSE" and "Organization encourages open communication about safety" 
Table 4: RII of Policy and Strategic Objectiveness

\begin{tabular}{|c|c|c|}
\hline Statement & RII & Rank \\
\hline Organization has a HSE Policy document & 0.619 & 8 \\
\hline $\begin{array}{l}\text { Organization manage and communicate } \\
\text { changes in HSE policy to all employees }\end{array}$ & 0.639 & 6 \\
\hline $\begin{array}{l}\text { Organization structured to manage and } \\
\text { communicate HSE effectively }\end{array}$ & 0.634 & 7 \\
\hline Organization ensure new employees have & & \\
\hline $\begin{array}{l}\text { knowledge, practices and requirements with } \\
\text { respect to HSE }\end{array}$ & 0.646 & 4 \\
\hline $\begin{array}{l}\text { There is a positive culture of HSE issues in } \\
\text { organization }\end{array}$ & 0.593 & 9 \\
\hline $\begin{array}{l}\text { Organization openly accepts ideas for } \\
\text { improving safety }\end{array}$ & 0.641 & 5 \\
\hline $\begin{array}{l}\text { Organization encourages open communication } \\
\text { about safety }\end{array}$ & 0.651 & 3 \\
\hline $\begin{array}{l}\text { Organization arranges to ensure new employees } \\
\text { have knowledge of basic HSE }\end{array}$ & 0.655 & 2 \\
\hline Organization really cares about my well-being & 0.684 & 1 \\
\hline
\end{tabular}

\subsubsection{Organization, resources and Documentation}

Table 5 shows the perspectives of Organization, resources and Documentation from client, consultant and contractor on relative importance of HSE Management System for Hotwork Operation at High Elevation in Shipbuilding Project in a single table. From the comparative view in Table 8, "Organization normally conduct incident/accident investigations" had been ranked as the most important factor by the groups (combining the views of client, consultant and contractor) followed by "Organization advise employees about PPE requirements at workplace" and "Organization provide Health and Safety training to employees".

Table 5: RII of Organization, resources and Documentation

\begin{tabular}{|c|c|c|}
\hline Statement & RII & Rank \\
\hline Organization provide training needs & 0.619 & 5 \\
\hline $\begin{array}{l}\text { Organization provide Health and Safety training } \\
\text { to employees }\end{array}$ & 0.634 & 3 \\
\hline $\begin{array}{l}\text { Organization advise employees about HSE } \\
\text { signage, proper use and compliance }\end{array}$ & 0.59 & 8 \\
\hline $\begin{array}{l}\text { Organization advise employees to find Project } \\
\text { Safety Plan \&OHS legislation on the site }\end{array}$ & 0.612 & 7 \\
\hline $\begin{array}{l}\text { Organization advise employees about PPE } \\
\text { requirements at workplace }\end{array}$ & 0.648 & 2 \\
\hline $\begin{array}{l}\text { Organization have made provision for HSE } \\
\text { communication meetings }\end{array}$ & 0.614 & 6 \\
\hline $\begin{array}{l}\text { HSE system are in place to monitor and prevent } \\
\text { worker from accident }\end{array}$ & 0.622 & 4 \\
\hline Organization manage PPE requirements & 0.508 & 9 \\
\hline $\begin{array}{lcc}\text { Organization } & \text { normally } & \text { conduct } \\
\text { incident/accident investigations } & \end{array}$ & 0.696 & 1 \\
\hline
\end{tabular}

\subsubsection{Evaluation and Risk Management}

Table 6 shows the perspectives of Evaluation and Risk Management from client, consultant and contractor on relative importance of HSE Management System for Hotwork Operation at High Elevation in Shipbuilding Project in a single table. From the comparative view in Table 9, "Personally I feel that safety issues are the most important aspects of my job" had been ranked as the most important factor by the groups (combining the views of client, consultant and contractor) followed by "Employees feel confident when they have all the training before perform at workplace" and "I can influence health and safety performance in this organization". 
Table 6: RII of Evaluation and Risk Management

\begin{tabular}{|c|c|c|}
\hline Statement & RII & Rank \\
\hline $\begin{array}{l}\text { Safety is the number one priority in the } \\
\text { organization when completing a job }\end{array}$ & 0.704 & 4 \\
\hline $\begin{array}{l}\text { Organization identify hazards, assess risks, control } \\
\text { and mitigation consequences, to a level as low as } \\
\text { reasonable practicable. }\end{array}$ & 0.667 & 6 \\
\hline $\begin{array}{l}\text { Organization provide identification, assessment, } \\
\text { control and recovery of hazards and effects }\end{array}$ & 0.634 & 7 \\
\hline $\begin{array}{l}\text { The project area plan been reviewed (including } \\
\text { hazards } \\
\text { utilities, excavations and restricted areas etc) }\end{array}$ & 0.571 & 10 \\
\hline $\begin{array}{l}\text { Immediate Manager/Supervisor show interest in my } \\
\text { safety at workplace }\end{array}$ & 0.687 & 5 \\
\hline $\begin{array}{l}\text { Organization send employees for risk assessment } \\
\text { training before they are allowed to perform their } \\
\text { work }\end{array}$ & 0.610 & 8 \\
\hline $\begin{array}{l}\text { Organization is advice of type environmental } \\
\text { hazards are associated with the scope of services }\end{array}$ & 0.588 & 9 \\
\hline $\begin{array}{l}\text { I can influence health and safety performance in } \\
\text { this organization }\end{array}$ & 0.776 & 3 \\
\hline $\begin{array}{l}\text { Employees feel confident when they have all the } \\
\text { training before performing at workplace }\end{array}$ & 0.916 & 2 \\
\hline $\begin{array}{l}\text { Personally, I feel that safety issues are the most } \\
\text { important aspects of my job }\end{array}$ & 0.918 & 1 \\
\hline
\end{tabular}

\subsubsection{Planning and Procedures}

Table 7 shows the perspectives of Evaluation and Risk Management from client, consultant and contractor on relative importance of HSE Management System for Hotwork Operation at High Elevation in Shipbuilding Project in a single table. From the comparative view in Table 10, "Organization ensure that work instructions and procedures are aligned with its HSE" had been ranked as the most important factor by the groups (combining the views of client, consultant and contractor) followed by "My immediate Managers/Supervisor express concern if safety procedures are not followed" and "Corrective action is always taken when management is aware about unsafe practices".

Table 7: RII of Planning and Procedures

\begin{tabular}{|c|c|c|}
\hline Statement & RII & Rank \\
\hline $\begin{array}{l}\text { Safety rules and procedures are carefully } \\
\text { followed in this organization }\end{array}$ & 0.658 & 4 \\
\hline $\begin{array}{l}\text { Health, safety rules and procedures are really } \\
\text { practical }\end{array}$ & 0.655 & 5 \\
\hline $\begin{array}{l}\text { Organization advise employees on the } \\
\text { procedures to refuse unsafe work }\end{array}$ & 0.610 & 9 \\
\hline $\begin{array}{l}\text { My immediate Managers/Supervisor express } \\
\text { concern if safety procedures are not followed }\end{array}$ & 0.670 & 2 \\
\hline $\begin{array}{l}\text { Corrective action is always taken when } \\
\text { management is aware about unsafe practices }\end{array}$ & 0.667 & 3 \\
\hline $\begin{array}{l}\text { Organization advised employee about changes } \\
\text { of procedures and tasks, and employee properly } \\
\text { prepared with complete safety training }\end{array}$ & 0.636 & 7 \\
\hline $\begin{array}{l}\text { Organization ensure that work instructions and } \\
\text { procedures are aligned with its HSE }\end{array}$ & 0.672 & 1 \\
\hline $\begin{array}{l}\text { Organization explained to employee about } \\
\text { unsafe act and inappropriate behavior at } \\
\text { workplace }\end{array}$ & 0.653 & 6 \\
\hline $\begin{array}{l}\text { Procedures of scaffold inspection and tagging } \\
\text { been explained to employee }\end{array}$ & 0.545 & 11 \\
\hline $\begin{array}{l}\text { The site's incident report procedures (including } \\
\text { near misses) been explained to employee }\end{array}$ & 0.624 & 8 \\
\hline $\begin{array}{l}\text { I feel some of safety rules and procedures do not } \\
\text { need to be followed to get the job done }\end{array}$ & 0.578 & 10 \\
\hline
\end{tabular}




\subsubsection{Implementation and Monitoring}

Table 8 shows the perspectives of Evaluation and Risk Management from client, consultant and contractor on relative importance of HSE Management System for Hotwork Operation at High Elevation in Shipbuilding Project in a single table. From the comparative view in Table 11, "Organization ensure employees are competent to perform a job that involves hazards and risks" had been ranked as the most important factor by the groups (combining the views of client, consultant and contractor) followed by "Organization ensure that infrastructure and equipment used within operations are correctly certified, registered, controlled and maintained" and "Organization frequently monitor HSE performance in the workplace".

Table 8: RII of Implementation and Monitoring

\begin{tabular}{|c|c|c|}
\hline Statement & RII & Rank \\
\hline $\begin{array}{llll}\begin{array}{l}\text { Organization } \\
\text { performance }\end{array} & \text { frequently } & \text { monitor } & \text { HSE }\end{array}$ & 0.619 & 6 \\
\hline $\begin{array}{l}\text { Many accident and near misses have occurred } \\
\text { while working for this organization }\end{array}$ & 0.612 & 7 \\
\hline $\begin{array}{l}\text { Organization frequently monitor } \\
\text { performance in the workplace }\end{array}$ & 0.639 & 3 \\
\hline $\begin{array}{l}\text { Organization ensure all employees have received } \\
\text { appropriate HSE training and it is recorded and } \\
\text { monitored }\end{array}$ & 0.622 & 5 \\
\hline $\begin{array}{l}\text { Organization ensure employees are competent to } \\
\text { perform a job that involves hazards and risks }\end{array}$ & 0.740 & 1 \\
\hline $\begin{array}{l}\text { Sometimes I must neglect some procedures/tasks } \\
\text { to complete the job }\end{array}$ & 0.561 & 9 \\
\hline $\begin{array}{l}\text { Conditions at workplace hinder my ability to } \\
\text { work safety }\end{array}$ & 0.602 & 8 \\
\hline $\begin{array}{l}\text { Organization ensure that infrastructure and } \\
\text { equipment used within operations are correctly } \\
\text { certified, registered, controlled and maintained }\end{array}$ & 0.733 & 2 \\
\hline $\begin{array}{l}\text { Organization frequently in place to control } \\
\text { hazards and monitor the effectiveness of these } \\
\text { controls }\end{array}$ & 0.636 & 4 \\
\hline $\begin{array}{l}\text { Organization frequently communicate with } \\
\text { employees about waste plan, a policy or } \\
\text { guidelines on waste management }\end{array}$ & 0.557 & 10 \\
\hline $\begin{array}{l}\text { Organization had sent employees for training } \\
\text { before they are allowed to erect, alter and } \\
\text { dismantle scaffolding or mobile towers }\end{array}$ & 0.494 & 11 \\
\hline
\end{tabular}

\section{ConCLUSION \& RECOMMENDATION}

The present condition of facing HSE Management System for Hotwork Operation at High Elevation in Shipbuilding Project in Malaysia was reviewed. This gives all the combination of factors may responsible for accidents in shipbuilding projects. The questionnaire survey and subsequent analysis gave different ranks for the factors from the perspective of combination of the three as client, consultant and contractor. There are 77 factors for HSE Management System for Hotwork Operation at High Elevation in Shipbuilding Project identified from the literature review, which were also ranked from the perspective of client, consultant and contractor based the results of the questionnaire survey and subsequent analysis.

The relative important index RII is calculated to rank the HSE Management System for Hotwork Operation at High Elevation in Shipbuilding Project. The statistical validity of the data collected using the questionnaire were tested by determining the normality and reliability of the data was tested using non-parametric testing methods namely the Pearson correlation and Cronbach's coefficient alpha. The responses were classified into three (client/owner, consultant, contractor) categories to facilitate the investigation in different viewpoints of the Malaysian shipbuilding industry. The statistical analysis was conducted using SPSS ver.22 for window to rank factors for three categories of respondents namely client/owner, consultant and contractor.

The present study is onsite works, health office and university campus, undertaken by the Malaysian shipbuilding industry; similarly, study can be proposed to the ship maintenance in Malaysia, involving the private owner, international consultants and contractors to differentiate the output from the different work cultures.

Studies also can be done for shipbuilding project with different operational environment in Malaysia's shipyard.

This paper proposed based on collaboration between UTP, UniKL MIMET, DOSH, Mof and shipyards that giving a very good support to complete the research. 


\section{References}

[1] Rodger Holdsworth, "Practical applications approach to design, development and implementation of an integrated management system”, Journal of Hazardous Materials 104 193-205, 2003.

[2] A. Akintoye, (2000) "Analysis of factors influencing project cost estimating practice", Construction Management and Economics, 18 (1) pp. 77-89.

[3] Calum MacLean \& Matthew Lewin, (2013) Achieving Hull Structural Hot Work Repairs on Boards and Operational FPSO, Marine Technical Limits Ltd, SPE 166625.

[4] Charles D. Reese, Occupational Health and Safety Management a Practical Approach, Second Edition, 2008.

[5] D.W.M. Chan, and M.M. Kumaraswamy, (1996) "An evaluation of construction time performance in the building industry", Building and Environment, 31 (6) pp. 569-78.

[6] N.E. Coviello, and M.V., Jones, (2004) "Methodological issues in international entrepreneurship research", Journal of Business Venturing, 19 (4) pp. 485-508.

[7] M.F. Dulaimi, F.Y.Y. Ling, and A. Bajracharya, (2003) "Organizatioanal motivation and inter-organizational interaction in construction innovation in Singapore”, Construction Management and Economics, 21(3), pp. 307-18.

[8] Fatih Yilmaz (2014) Analysis of Occupational Accidents in Construction Sector in Turkey, Journal of Multidisciplinary Engineering Science and Technology (JMEST) ISSN: 3159-0040, 1(5).

[9] C. M. Floriano Pires Jr and Thomas Lamb, Establishing performance targets for shipbuilding policies, Marit. Pol. Mgmt., October 2008, 35 (5) 491-502, 2008.

[10] Heinz-Peter Berg, Risk Management: Procedures, Methods and Experiences, Bundesamt für Strahlenschutz, Salzgitter, Germany, 2010.

[11] J. G. Pouzou, Confined Space Ventilation by Shipyard Welders: Observed Use and Effectiveness, Published by Oxford University Press on behalf of the British Occupational Hygiene Society, 2014.

[12] R. Jeffrey Walls, Characterization of Work Practices and Ventilation Techniques in Shipyard Confined Space Welding, A Thesis, Public Health-Environmental and Occupational Health Sciences, University of Washington, (2012)

[13] Nabilah Ghazali, Siti Khalijah Yaman \& Hairuddin Mohammad, Contractors' Compliance on Occupational Safety and Health (OSH) Policies in Malaysia's Construction Industry, Faculty of Civil and Environmental Engineering, Universiti Tun Hussein Onn Malaysia Johor, Malaysia, 8th MUCET 2014, 2014.

[14] T.T. Sin, (1991) Managing process in Bumiputra Society-Malaysia. In: J. Putti, ed. Management Asian context. Singapore: McGraw-Hill, 1-5.

[15] J. Kennedy, and N. Mansor, (2000) Malaysian culture and the leadership of organizations: a GLOBE study. Malaysian management review, 35, 44-53.

[16] Terence N. Taylor, Lieven Eeckelaert, Annick Starren \& Arjella van Scheppingen, David Fox, Carsten Brück, Occupational Safety and Health culture assessment - A review of main approaches and selected tools, European Agency for Safety and Health at Work (EU-OSHA), 2011.

[17] Floriano C. M. Pires Jr and Thomas Lamb, Establishing performance targets for shipbuilding policies, Marit. Pol. Mgmt., October 2008, 35(5) 491-502, 2008.

[18] M. N. Ustadi \& P. N. H. M. A. Rahman, (2013) The Architecture of Logistics Management System for Private Enterprise, MIMET Technical Bulletin, 4(2).

[19] Baris Barlas "Shipyard fatalities in Turkey”, Safety Science 50 1247-1252, Feb 2012.

[20] Yen-Hui Lin, Chih-Yong Chen, Min-Hsien Cho, "Effectiveness of leg movement in reducing leg swelling and discomfort in lower extremities", Applied Ergonomics 43 (2012) 1033e1037, Mac 2012.

[21] Yen-Hui Lin, Chih-Yong Chen, Min-Hsien Cho, "Influence of shoe/floor conditions on lower leg circumference and subjective discomfort during prolonged standing", Applied Ergonomics 43 965e970, Jan 2012.

[22] Ahmed Ilyas Yilmaz, Fatih Yilmaz and Ugur Bugra Celebi, Analysis of Shipyard Accident in Turkey, British Journal of Applied Science \& Technology, 5(5): 472-481, 2015. 
[23] S.G. Odewumi \& M.S. Ajisegiri, (2013) An appraisal of Environmental Health \& Safety Management in The Workplace (A Study of Continental Shipyard Limited), Centre for Environmental Studies and Science Education, Lagos State University, Ojo, Lagos, Nigeria.

[24] Chan, D.W.M. and Kumaraswamy, M.M., (1996) "An evaluation of construction time performance in the building industry”, Building and Environment, 31(6) pp. 569-78.

[25] Robert P. Anderson, Daniel Lewc, A. Townsend Peterson 'Evaluating predictive models of species' distributions: criteria for selecting optimal models’, Ecological Modelling 162 (2003) 211-232, 2003.

[26] Kari Kuulasmaa, Hanna Tolonen, Päivikki Koponen \& Katri Kilpeläinen, An overview of the European Health Examination Survey Pilot Joint Action, National Institute for Health and Welfare (THL), Helsinki, Finland, 2012.

[27] Daniel W.M. Chan, Albert P.C. Chan, Patrick T.I. Lam, John F.Y. Yeung, Joseph H.L. Chan, "Risk ranking and analysis in target cost contracts: Empirical evidence from the construction industry", International Journal of Project Management,29(6) Pages 751-763, Aug 2011.

[28] Nicole E Coviello \& Marian V Jones, "Methodological issues in international entrepreneurship research", Journal of Business Venturing,19(4) Pages 485-508, July 2004.

[29] , M.F. Dulaimi, F.Y.Y. Ling, and A. Bajracharya, "Organizatioanal motivation and inter-organizational interaction in construction innovation

in Singapore",

[30] Construction Management and Economics, 21 (3) pp. 307-18, 2003.

[31] U. Sekaran, \& R. Bougie (2000) "Research Methods for Business: A Skill Building Approach (15th Ed.)", Chichester: John Willey \& Sons Ltd. 